Some Facts Concerning New York State College

537

CrN4

UC-NRLF

||||||||||||||||||||.||||||||||||||

5B 34705

m

तै

ก

บ 


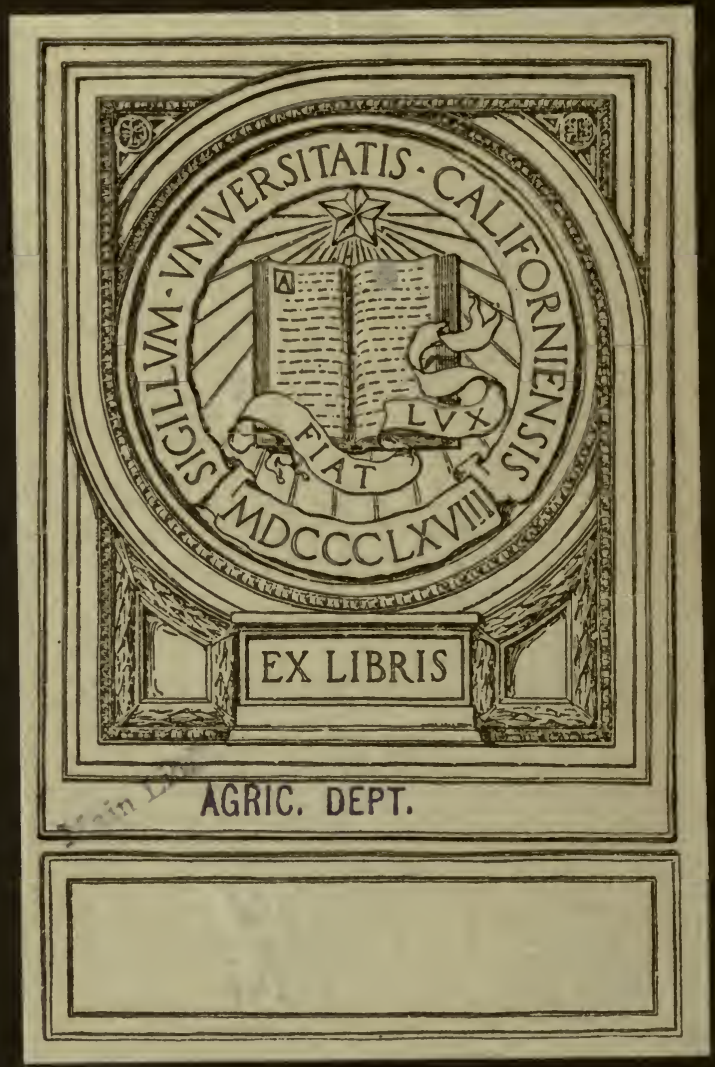


Some Facts Concerning

The New York State

College of Agriculture

At Cornell University

Ithaca, N. Y.

By H. J. WEBBER

Acling Direclor

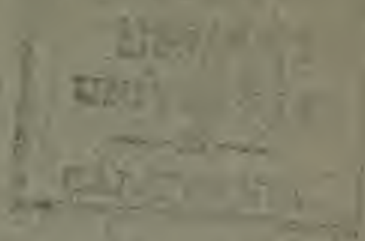





\title{
Some Facts Concerning
}

\section{The New York State College of Agriculture}

\section{At Cornell University}

\author{
By H. J. WEBBER \\ Acting Director
}

PRESENTED TO A HEARING OF LEGISLATIVE COMMITTEES, ALBANY, APRIL 5, 1910.

ITHACA, N. Y., MARCH, 1910 


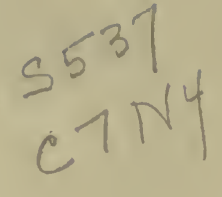

\section{INTRODUCTION.}

Agriculture in the United States is advancing rapidly, and nowhere is there manifest more activity or more wide-spread interest than in New York. This general activity is doubtless due largely to increased cost of living and better returns from farm products. Farm lands in the state are increasing in value and there is every evidence that we are entering a period of great agricultural development and prosperity. While New York is perhaps not so wholly dependent on its agricultural interests as some of the western and southern states, still it ranks fourth among the states in the value of its agricultural products, having a total value in 1899 , the last census year, of $\$ 245$,270,600 . Agriculture will always be the principal industry in the greater part of the state and the foundation of its prosperity.

With the renewed interest in agriculture, increasing demands are being made on the educational institutions of the state to provide training in agricultural subjects. Farmers want their sons and daughters to take up farming as their life work fitly prepared for it. Farmers themselves are demanding training in advanced scientific methods. City men and boys in ever increasing numbers desire to go on farms and are looking for places to secure the necessary training. The state has adopted the policy of providing institutions where such education can be obtained, having established a college of agriculture and three special schools of agriculture, besides having begun the introduction of agricultural studies into the common schools and high schools. The state is now facing the question as to whether it will develop its existing institutions to meet their immediate demands, or whether the progress shall be arrested. The leadership in this forward movement should rest with the State College of Agriculture. It must dispense information and rouse the people by putting before them better methods and higher purposes. It must find new truth and carry the discoveries of investigators to the people on the farms. It.must train teachers for the teaching of agriculture in the secondary and high schools. Its work must be constructive and it must point the way.

The New York State College of Agriculture at Cornell University, through its investigations and bulletins, its lectures and demonstrations with farmers, and its large number of students receiving instruction, is 
rendering its best service to the people of the State. If it has not met all expectations, it is largely because its facilities have been almost trivial as compared with the work it has been expected to do. The demands that come to the College from the folks on the farms and in the rural schools are far and away beyond the facilities for meeting them. The capacity of the College for effective resident teaching is taxed much beyond its limits this year in caring for the 968 students; and the student body is increasing at the rate of 150 students per year. The mere increase in number of students makes demands on teachers and equipment that few persons understand. It is not merely a question of finding a place where students may sit, but desks, microscopes, special apparatus, animals, library facilities, and the like.

The work of the College is for the people. It is the people of the State that make the demands and the College looks to the people for its support. To carry forward the work which is being crowded upon the College in greater volume and with greater persistency each year, greatly enlarged facilities must be provided.

Bills are now before the Legislature of the State providing for the further buildings needed immediately, and for the increased maintenance which must come if the College is to meet the demands of the state work. It is the purpose of this circular to state certain facts regarding the College which the people of the state should know.

Regarding the work of the College, Dean Bailey stated during the 1909 Farmers' Week: "We are conducting reading-courses with less: than 16,000 farmers and farmers' wives in New York, yet there are a half million such in the State. We are reaching at this moment less than 7,000 teachers, but there are 40,000 school teachers in the State and hundreds are being prepared each year. We are reaching 65,000 children this year, out of one and one-half million in the elementary and ligh schools of the State. We are conducting demonstrations or test work on some 300 farms out of the 227,000 in the State. We are teaching one student for about every 500 farms. In this College of Agriculture, large as it has grown to be, we yet have less than one student to each rural township in the State. There are probably more farm boys: and girls in any one agricultural county in the State than are now in this College of Agriculture. All this is in spite of the fact that the number of students is increasing so rapidly that we cannot properly keep up with the work. The value of farm property in New York in the last census year was $\$ 1,069,723,895$. The money appropriated for maintenance of college education in agriculture is about one sixty-sixth of one per cent. of the valuation." 


\section{COMPARISONS WITH OTHER COLLEGES OF AGRICULTURE.}

The buildings of the College of Agriculture devoted to purposes of instruction, for laboratories, class rooms and offices, cost the State for construction and equipment $\$ 340,000$, and furnish 120,662 feet of floor space. With the present attendance of 968 students, this gives a floor space per student of 125 sq. feet. This is much less floor space per student than is provided in any of the other State Colleges of Agriculture that rank with the New York State College. As an illustration of the space per student furnished in other State Colleges, the following may be given, computed from statements given to the writer on a recent visit to these colleges: Wisconsin, 208 sq. ft.; Illinois, 305 sq. ft.; Minnesota, 223 sq. ft. ; Iowa, 350 sq. ft.

The cost of the agricultural buildings and barns in all of the institutions mentioned in the preceding paragraph exceeds the cost of those of the New York State College of Agriculture.

In the New York State College of Agriculture the number of regular long-course students and post-graduate students exceeds considerably that of any of the above institutions, except Illinois, which has only a slightly less number than New York. The higher grades of students would naturally be expected to require more space for their work than the lower grades.

The faculty of the New York State College of Agriculture, now numbering 83 professors, instructors and assistants of all grades, exclusive of student assistants, stenographers and workmen, is larger than that of any other institution.

The Empire State should give more liberal support in the development of its State College of Agriculture. Other Colleges of Agriculture are forging ahead, and if New York is to keep pace with the institutions in other states, and if it is to meet its own need for agricultural education, greatly increased facilities will have to be provided for the College of Agriculture, particularly in buildings for laboratory, class room, and experimental work. 


\section{ORGANIZATION OF THE NEW YORK STATE COLLEGE OF}

\section{AGRICULTURE.}

Cornell University is founded on the Congressional Land-Grant Act of 1862, and agriculture, therefore, has been a part of its work from the beginning. In the early days of the University, the agricultural teaching was given in a Department of Agriculture. In 1896 the University was divided into eight colleges, of which the College of Agriculture was one. By act of the legislature, Chapter 655 of the Laws of 1904, approved by Governor Odell, May 9, 1904, the College of $\Lambda$ griculture was established as a State Institution under the title of "The New York State College of Agriculture at Cornell University." This act carried an appropriation of $\$ 250,000$ for buildings. An Administration Act became a law by the signature of Governor Higgins April 12, 1906, and that year the Appropriation Act carried a maintenance item of $\$ 100,000$ for the College of Agriculture.

CONTROL OF THE COLLEGE OF AGRICULTURE.

The control of the College of Agriculture is vested in the Board of Trustees of Cornell University. The State is represented on the Board by the Governor, Lieutenant Governor, the Speaker of the Assembly, the Commissioner of Education, the Commissioner of Agriculture, exofficio, and by five members appointed by the Governor. The people are further represented by the President of the State Agricultural Society and by a Trustee appointed by the State Grange. Ten members of the Board are elected by the alumni. The fifteen remaining elective members of the Board are chosen by the Board itself. It will be seen from the above statement that the State now has equal control with the alumni in the government of the University and thus of the College of Agriculture.

HOW THE COLLEGE SERVES THE STATE.

The New York State College of Agriculture is endeavoring to serve the agricultural interests of the State by the following means. All courses in the College are free of tuition to residents of the State:

INSTRUCTION AT THE COLLEGE.

The Four-Year Course in Agriculture.-This course is of equal 
academic rank with other courses in Cornell University and leads to the degree B. S. in Agriculture. It offers a thorough theoretical and practical training in agricultural and country-life subjects. The equivalent. of a high school training is necessary for admission. The following subjects are offered in the college:-Botany, agricultural chemistry, soil technology, plant physiology, plant breeding, farm crops, farm management, horticulture, farm mechanics, farm practice, plant pathology, general biology, entomology and general invertebrate zoology, animal husbandry, poultry husbandry, dairy industry, rural economy, drawing, rural art, home economics, meteorology, extension, and nature-study.

Rural Art Course, comprising the junior and senior years in the four-year course, providing instruction in landscape gardening and related subjects.

Home Economics Course, comprising the junior and senior years in the four-year course, with facilities for practical work.

Nature-Study Special Course.-For those who desire to prepare themselves to teach elementary agriculture and nature-study. Open to teachers or students in the University who are fitting themselves for teaching. Two years.

Special Work in Agriculture.-For those who are unable to take the full four-year course. There is no examination for admission, but the students must have finished satisfactorily the common school studies. Special students take those studies which will be most valuable to them in the various departments, and which they are qualified to pursue. This work is designed especially for those who wish to fit,themselves for successful farming, but who cannot take a four-year course. About two years can be profitably spent in such work. The applicant must present full credentials and testimonials, and each case is considered by itself on its merits.

Winter-Courses, five in number: 1, General Agriculture; 2, Dairy Industry ; 3, Poultry Husbandry ; 4, Horticulture; 5, Home Economics.

These courses are for 12 weeks, beginning the first week in December and closing the last week in February. Non-residents of the State pay a tuition fee of $\$ 25$.

Scholarships and Fellowships in Agriculture.-For Regular and Special Students. The Roberts Scholarships are five in number, for students who show ability, tact and application, who are of good moral character, who are in need of financial assistance, and especially for those from rural districts. No examination is required and the value of 
each is $\$ 240$. A fellowship worth $\$ 500$ is awarded to the College of Agriculture and the Veterinary College combined.

For Winter-Course students.-Twelve scholarships are given each year by the New York State Grange. Value $\$ 50$ each. Given only to Grange members, and to the twelve who attain the highest average in a competitive examination.

MIr. H. L. Beatty has offered for the year 1909-1910 a scholarship of $\$ 75$ in value, "open to any farmer residing in Bainbridge, or to any boy over 16, residing in Bainbridge, who shall have attended the Bainbridge High School for one full term."

\section{INSTRUCTION IN THE STATE.}

Farmers' Reading-Course.-For those who are unable to leave their work but desire to learn. Practical bulletins on agricultural subjects are periodically sent to the reader and correspondence is encouraged. These courses discuss : 1 , Soils and Crops ; 2, Stock Feeding ; 3, Orcharding ; 4, Poultry ; 5, Dairying; 6, Buildings and Yards; 7, Helps for Reading; 8, Miscellaneous; 9, Breeding; 10, Horse Production. Free to persons residing in New York. Forty-seven such bulletins have been issued, averaging about 18 pages each, and these go regularly to about 5,000 reader's.

Farmers' Wives' Reading-Course.-These are popular bulletins discussing household economy, cooking, home furnishing, sanitation, and the like. They are used especially in connection with a readingcourse conducted by correspondence. Thirty-four such bulletins have now been issued, having an average of about 24 pages each. These go regularly to about 15,000 readers.

Nature-Study.-Extension work is conducted for teachers and pupils particularly in the rural schools. One publication is issued in the interests of the work, - the Home Nature-Study Course, quarterly, following the State Syllabus. The readers of this course now number 5,341 .

Rural School Education.-Farm Boys' and Girls' Clubs are organized and directed in connection with the work in rural schools. One publication is issued in the interest of this work,-the Cornell Rural School Leaflet, monthly, for pupils, and a Supplement for teachers. Twenty-seven publications have been issued in this series, averaging about 18 pages each. These go to about 65,000 children and 6,000 teachers. 
Co-operative Experiments in Agriculture.-The college co-operates with farmers in making experiments on their land that will be of direct practical value to them. The organizations that are now co-operating with the college are: The New York State Experimenters' League; The New York State Drainage Association; The New York State PlantBreeders' Association, and 'The Housekeepers' Conference.

Special Lectures.-Lectures are given, upon request, by members of the College Faculty at such times and places as can be arranged, before Granges, Farmers' Reading-Course Clubs, Farmers' Institutes and other Agricultural Societies, Schools and Public Assemblies.

State and County Fair Exhibits.-The College, through an Educational Exhibit and Information Bureau, co-operates with the State Fair each year, and with as many County Fairs as practicable.

Special Farm Trains.-Occasionally a "Farm Special" train is run through a certain section of the State, and stops are made at previously scheduled and announced places, where discussions are held. Three such trains have already been run, and others are now under consideration.

Farmers' Week.-This is a week for the gathering of farmers and farmers' wives at the College. Lectures and demonstrations by members of the Faculty, by successful farmers, specialists and others who have achieved distinction in agriculture are given throughout the week. The museums of the College and the University are opened, and the various departments prepare special educational exhibits. The Agricultural Experimenters' League, the New York State Plant Breeders' Association, the State Drainage Association, and various other agricultural societies hold meetings here at this time. The attendance during these Farmers' Weeks has ranged from 1500 to 2800.

Excursions.-A large number of Granges, Farmers' Clubs, and cther organizations come to the College during the warm months of the year. Meeting places and other facilities are provided for such agricultural organizations which may wish to meet at the College, and aid is given by furnishing speakers and demonstrations to make the meetings profitable.

Bureau of Information.-Questions pertaining to farm problems are referred to various Departments of the College for answer. In this way much information is given in a very direct and special way. About 40,000 such communications have been answered in the past year.

The Experiment Station.-The staff of the Experiment Station is endeavoring to solve some of the more pressing agricultural problems 
of the State. The results of this work are published in the form of bulletins which are sent free to residents of New York State.

Up to the present time there has been issued from the Experiment Station 273 different bulletins, giving the results of experiments and observations. These had an average of about 24 pages each. The numher of copies published of each bulletin ranges from 3,000 to 30,000 .

Short circulars on agricultural topics, varying in length from four to eight pages and in editions from 3,000 to 10,000 copies, are also issued from time to time.

The size of the editions and the number of readers in each of the series of publications of the College of Agriculture by no means indicate the interest manifested by the people of the State in these publications. It is necessary in all cases to revise and reduce the mailing list each year. In the Reading-Course for Farmers, the publications are sent cnly to those returning the question blank that goes out with each publication. For the Rural School Leaflets the mailing list is made up cntirely new each year from direct requests, yet quickly again reaches the 65,000 to 75,000 limit.

It is believed that it is not too high an ideal to expect that at least one of the bulletins illustrating the investigations of the College should go into each home in the State interested in agriculture at least once a year, yet this ideal is nowhere near accomplishment, and the funds available for publication will not permit such a distribution. With few exceptions the editions of bulletins in all of these classes are too small to meet the demands and are soon exhausted; the available funds will not admit of larger editions.

\section{STUDEN'TS IN THE COLLEGE OF AGRICULTURE}

The number of students attending the College of Agriculture has increased very rapidly in recent years. During the first twenty years, from 1868 to 1887 , the total number of students in any year did not exceed fifty in number. In the year 1892-3 the short winter-course was added, and the total number of students reached 103. There followed a gradual increase until in the year 1903-4 the total registration reached 296. In the spring of the year 1904 the College became a State institution, and an appropriation granted for the erection of buildings. As a result the registration for the succeeding year, 1904-5, advanced to 418 . From that time the increase has been constant, and in the five-year period since, the registration has more than doubled, being this year a total of 968 students of all grades. This increase is graphically illustrated in the accompanying chart. 


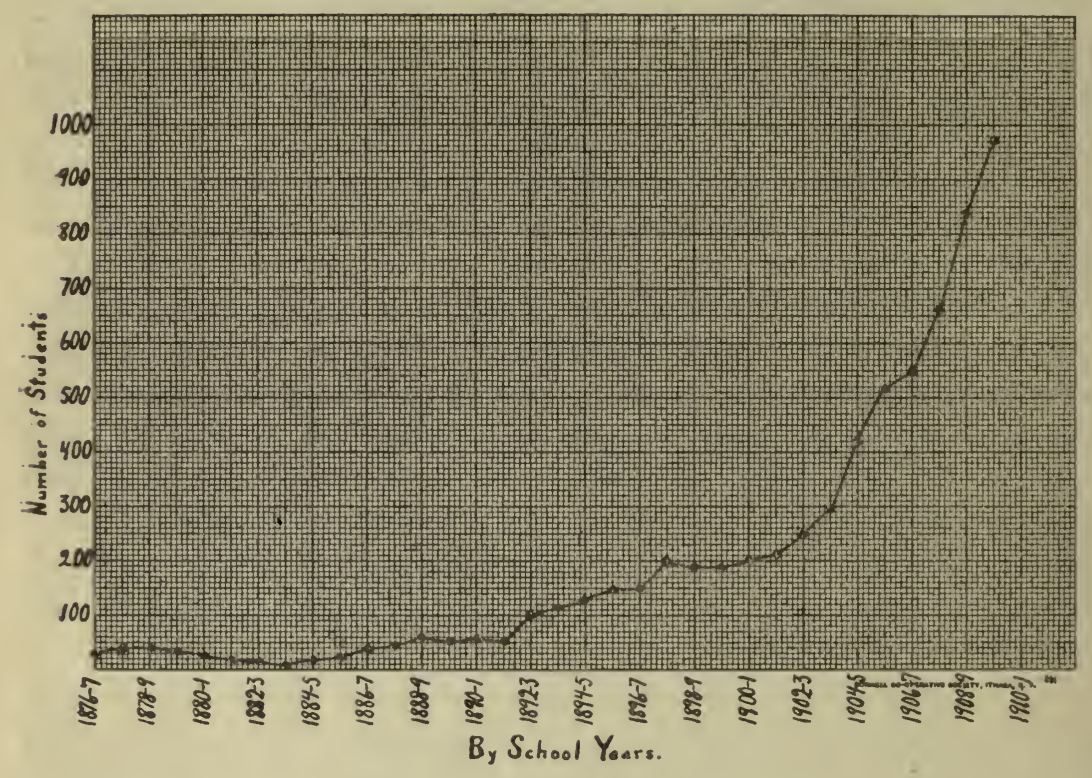

The registration of various grades of students since the College became a State institution is shown in the following table:

REGISTRATION OF STUDENTS FOR LAST SIX YEARS.

\begin{tabular}{|c|c|c|c|c|c|c|}
\hline & $1904-5$ & $1905-6$ & $1906-7$ & $1907-8$ & $1908-9$ & $1909-10$ \\
\hline Regulars . .... & 98 & 129 & 145 & 209 & 272 & 419 \\
\hline Specials . ...... & 90 & 95 & 124 & 138 & 144 & 120 \\
\hline Post-Graduates .. & 31 & 40 & 36 & 43 & 58 & 58 \\
\hline Winter-Course ... & 199 & 253 & 244 & 270 & 364 & 371 \\
\hline Totals & 418 & 517 & 549 & 660 & 838 & 968 \\
\hline
\end{tabular}

The registration of Winter-course students in 1909-10 would have been considerably larger had it not been found necessary to limit the registration.

\section{PERCENTAGE OF STUDENTS FROM NEW YORK STATE.}

It has been stated that a large proportion of the students of the College of Agriculture come from foreign countries and other states. A correct idea of the distribution can be obtained from the following table: 


\begin{tabular}{|c|c|c|c|}
\hline Students & $1907-8$ & $1908-9$ & $1909-10$ \\
\hline From New York.............. & 474 & 610 & 706 \\
\hline From other states............. & 146 & 188 & 213 \\
\hline From foreign countries.......... & 40 & 40 & 49 \\
\hline & 60 & 338 & \\
\hline
\end{tabular}

It will be seen from an examination of the above table that for the last three years 72.6 per cent. of the students have come from the State of New York. It is important that the significance of out-of-state students be not incorrectly estimated. The number of out-of-state students is one indication of the esteem in which the work of the New York State College of Agriculture is held; and one of the most valuable features of a large institution with a cosmopolitan student body is the contact with persons from other states and other countries with different ideals, practices and customs.

Moreover, a part of the support of the College of Agriculture is provided from Cornell University funds, and the University does not confine its activities to the State. No State College of Agriculture, so far as the writer can learn, limits its attendance to residents of the state, and it would probably be a mistake to ever make such limitations.

\section{OCCUPATIONS OF FORMER STUDENTS.}

The statement is frequently made that Agricultural Colleges educate away from the farm. A few years ago a tabulation was made of the occupations of former students so far as they could be learned at that time. The results are given in the following table: 
Agricultural College and Experiment Station Work.

U. S. Department of Agriculture

Farmers, Nurserymen, Farm Mgrs., etc.

Creameries, Cheese Factories, etc.

Editors

Landscape Architects

Physicians

Students

Miscellaneous

Died

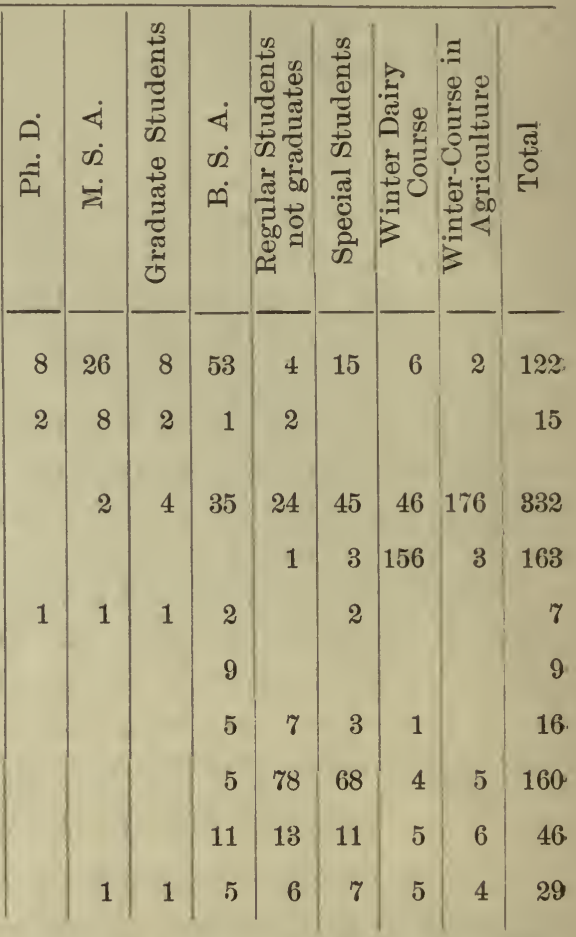

Of the total number of living former students who were not at that time in school and whose occupation could be learned, 71 per cent. were in some form of farm work, 20 per cent. were in some form of agricultural education work, or a total of 91 per cent. were either farming or pursuing some line of work directly allied to agriculture. Certainly it cannot be maintained that the New York State College of Agriculture educates away from the farm. Moreover, the tendency toward the farm is strongly increased. It is very doubtful whether any other type of professional or technical college could show a larger percentage of graduates and former students who are following the profession for which they prepared.

All of our agricultural colleges, particularly those connected with Universities, are influencing a very large percentage of their students to pursue practical agricultural work. Of the 206 graduates of the Illinois College of Agriculture, 113 are actually on farms and 82 in some other 
form of agricultural work; 95 per cent. are thus engaged in some kind of agricultural work.

\section{VALUE OF HIGHER EDUCATION TO THE FARMER.}

In connection with the farm management investigations of the College, some very suggestive evidence has been secured showing the money value of education in farming. In a number of townships all of the farms were visited and accurate data obtained from the farmer showing his income from his own labor. In deriving the farmer's labor income, from the gross receipts there were deducted all expenses, including those for labor other than that of the farmer himself, five percent. interest on capital invested and a charge for depreciation in apparatus, tools, etc. Record was also made of the highest school the farmer had attended. Complete data were secured from 573 men. The. results were as follows:

Number of Average labor farmers income Attended district school only............ $398 \quad \$ 318$ Attended high school or equivalent......... $165 \quad \$ 622$ Attended college or university........... $10 \quad \$ 847$

It might be assumed that these differences were due to the high school men having had better farm opportunities. To eliminate this difference, the farms were arranged in groups having equal capital:

\begin{tabular}{rrr|rr}
\hline Capital & $\begin{array}{c}\text { Average labor income of } \\
\text { farmers with district } \\
\text { school education }\end{array}$ & $\begin{array}{c}\text { Average labor income of } \\
\text { farmers with more than } \\
\text { district school educa- } \\
\text { tion. }\end{array}$ \\
\hline 2000 and under & $\$ 187$ & $\$ 286$ \\
2001 & to & 4000 & 241 & 275 \\
4001 & to & 6000 & 398 & 466 \\
6001 & to & 8000 & 395 & 709 \\
8001 & to 10000 & 618 & 796 \\
10001 & to 15000 & 525 & 1091 \\
over & & 15000 & 1054 & 1272 \\
\hline
\end{tabular}

From this table it appears that in every group the men having the highest education made the best use of their capital. From the first table we see that there is an increase of $\$ 304$ per year in labor incomeof those men who have attended high schools. Therefore we may conclude that "a high school education is worth more to these farmers. than an endowment of $\$ 6,000$ in 5 per cent. bonds." 


\section{ILLUSTRATIONS SHOWING THE VALUE OF THE EXPERI- MENTAL WORK OF THE COLLEGE.}

It is impossible in this circular to discuss in any detail the experimental work of the College. The few illustrations given under this heading, however, will indicate the general nature of the work and its value to the agriculture of the State.

Experiments showing how dairying in New York may be improved. - In 1873 the College of Agriculture owned a herd of ordinary cows, the average yield of which was about 3000 pounds of milk per cow per year. In this year, Professor I. P. Roberts purchased a pure-bred bull and began to breed and grade up the herd, retaining the best animals and constantly "weeding out" the less productive ones. This process has been steadfastly continued up to the present time, with the result that in the year which ended August 31, 1909, thirty-seven cows in the herd of the College of Agriculture averaged 7463 pounds of milk containing 302 pounds of fat, and yielding a gross return of $\$ 120$ per cow, or a little more than double that yielded by the original herd.

What this would mean to the farmers of the State is seen from the statement that in 1899 the average production of the cows in the state of New York, as given in the United States Census Reports, was 4378 pounds. The methods employed in this improvement are those that are within the means of any farmer or dairyman. No expensive animals have ever been purchased, and practically all of the present members of the herd have been raised upon the place. If all of the farmers in the State for the past thirty-five years had practiced these same methods, the annual yield of the average cow in the state of New York would casily be twice its present amount.

The cow-testing work of the Dairy Department has enabled the farmer to know the total amount of milk and butter-fat made by each .cow in his herd and the value of feed consumed by each cow. It has been found in some herds that certain cows were not producing enough to pay for their feed, while other cows in the same herd were producing a return of over $\$ 50.00$ in excess of the feed consumed. The information obtained from this work enables the farmer to dispose of his poor cows and raise the heifer calves from his best ones, in this way steadily raising the productive capacity of his herd. The data on which the above statement is based was obtained from the records of twenty herds containing a total of 209 cows. The value of this work can be shown by the following illustration:

The average milk production per cow in New York State is at 
present not far from 4400 pounds per year. This average might easily be raised to 7000 pounds per cow by adopting the methods used in cowtesting work. This would mean an average increased production per cow for the entire state of 2,600 pounds per year. Considering the number of cows in the state to be $1,800,000$, this would give an increased production of milk of $4,680,000,000$ pounds. Figuring this at $\$ 1.30$ per hundred, it gives an increased return to the dairymen of the State of $\$ 60,840,000.00$ per year.

Experiments showing how New York State butter-making may be improved.-The results of the work in determining the moisture content of butter will make it possible for butter-makers to produce a more uniform product which will bring a higher price on the market, and also to produce more butter from a given amount of cream, thus giving the butter-maker and the milk-producer an increased profit in two ways. The profits of such work may be as great as indicated by the following illustration:

Suppose a creamery receives an average of 10,000 pounds of milk per day. The difference in the cash returns to this creamery resulting from butter containing $14 \%$ of moisture as compared with butter containing $9 \%$ of moisture, is equal to $\$ 6.30$ per day or $\$ 2,299.50$ per year. This fact was determined by experiment.

Poultry investigations.-The Poultry Department has conducted experiments which have shown

(1) That the practice of starving hens to force a molt results in loss instead of gain, the difference amounting to 25c per fowl per year (Bulletin 258).

(2) That constitutional vigor is a vital factor in the successful handling of poultry; that it can be recognized by external characters; that these characters are hereditary and that the constitutional vigor of fowls influences molt, fertility and hatching power of eggs, size and vigor of chicks and prolificacy, amounting to twelve to fourteen eggs per hen per year and 35c to $40 \mathrm{c}$ per year profit per hen (Reading-Course Bulletin 45).

(3) That the supplying of ground feed as a dry mash in the feedhoppers materially reduces the labor, increases production, decreases mortality, and increases the net profits in the feeding of fowls (Bulletin 249).

(4) That chickens may be reared in flocks of two hundred by the use of a gasoline-heated colony-house system, which reduces the cost of 
the original investment and decreases the labor in feeding and brooding seventy-five per cent. (Bulletin 246).

(5) A large number of labor-saving and sanitary poultry appliances have been invented and given to the public, among which are indoor and outdoor feed-hoppers, a combination refrigerator crate for eggs and dressed poultry, watering devices, trap nest, etc. (Bulletin 248).

(6) Improved types of poultry houses have been adapted to New York State conditions as a result of experiments with different types of houses. (Reading-Course Bulletins 16 and 33, and Circulars 1 and 3). Alfalfa on sterile hill lands. - The College farm consists largely of a heavy, tenacious soil known as Dunkirk clay loam. This is a type of soil that has been regarded as especially unsuited for alfalfa-growing. About 1903, a study was begun to ascertain whether it is possible to grow alfalfa on this soil, and if so, what treatment of the crop is necessary to secure success. An acre of land was fitted and seeded in the summer of 1906. Harvests have been secured from it during the three succeeding seasons. In 1907, the yield from one acre was 3 tons and 1500 pounds of well-cured hay ; in 1908, 3 tons and 500 pounds; in 1909, 6 tons and 360 pounds, - a total of 13 tons and 360 pounds for the three years.

During this period alfalfa hay has varied in price from fifteen to twenty-one dollars per ton. Figuring at the minimum price per ton, the cash value of the three seasons' product of one acre of land was $\$ 197.70$. Since the season of seeding there has been no labor or expense for fertilizer given this land except in the harvesting of the crop.

There has been expended for labor, lime, manuring and seed about fifty dollars per acre. This, of course, is a large expenditure in getting the crop started, but when it is considered that no further expense is incurred, except the harvesting, for a series of eight to fifteen years, and with fair prospects of the average yields as they have been in the past, it will be seen that this experiment demonstrates that there is a great cpportunity for financial success in growing alfalfa on this type of soil, notwithstanding the natural difficulties to be met.

It is demonstrated by this experiment that to secure successful alfalfa crops on Dunkirk clay loam, a very common type of soil over about one-third of the State, it is necessary that the land shall be well manured the season of sowing, dressed with lime and inoculated by means of soil from an old alfalfa field.

The use of lime.-Investigations indicate that in the neighborhood of 75 per cent. of the farm land will respond profitably to the use of 
lime. In many cases, its use is fundamental to the profitable growth of crops and necessary to the maintenance of soil fertility.

Our investigations have shown that the use of lime by promoting nitrification, particularly in connection with a legume, increases the nitrogenous substance in both the legume and the non-legume, thereby materially increasing the food value of all these substances, and consequently adding materially to the value of the crop.

Better yielding timothy.-In timothy-breeding experiments conducted by the Experiment Station, over 40,000 individual plants have been tested and about 200 distinct strains have been secured. Some of the best of the select types have in our experiments produced twice the average yield of all the plants tested. As seed has been grown and tested from almost every hay-growing section of the world, we are safe in assuming that the thousands of plants which we have tested represent the average of what would be found in ordinary hay fields. New York is the first state in the Union in the number of acres of hay produced, and in total production ranks first, with over $6,000,000$ tons having a farm valuation of about $\$ 70,000,000$. The average yield per acre in New York is 1.2 ton, which makes it rank forty-fourth among the states in the average production per acre. By the use of these new select strains the yield of hay would be increased at least one-fourth. The importance to the State of such an increase will be clearly apparent when the size of the crop is considered. Coupled with greater yield, some of the new strains are resistant to rust and avoid the injury which is produced by this serious malady.

Control of insect pests.-The life history and habits of the codling moth have been exhaustively investigated and a definite and effective method of control demonstrated whereby hundreds of thousands of dollars have been saved to the apple-growers of New York State.

After a careful study of the habits of the cabbage maggot, a remedy was prescribed that still remains the most effective one ever devised.

The pear-tree psylla threatened the extinction of pear-growing in certain parts of the State, but by a careful study of its life history an effective remedy was found that saved many orchards. In 1892, Mr. G. T. Powell estimated that he lost 1100 barrels of pears through the work of the pear-tree psylla. Other growers lost in similar proportions. The control of the psylla saved hundreds of thousands of dollars to the pear-growers of the State.

The investigation of wire-worms, the peach-tree borer, bud-moth, grape-vine flea-beetle, grape root-worm, grape-berry moth, pistol-case 
borer, cigar-case borer, apple-seed chalcis fly, and others have been carried to completion and helpful methods of control have been devised.

In 1900 there were approximately 15 million bearing apple trees in New York that produced over 24 million bushels of apples. Spraying for the codling moth is so universal and so effective in increasing the quantity and quality of marketable apples that if we were so conservative as to estimate an increased average income from each tree through spraying to be $25 \mathrm{c}$, we should have a profit of more than $\$ 3,000,000$ accruing to New York apple-growers each year through the control of this one insect as a result of the application of the arsenical sprays. The first spray calendar ever published was prepared in the Department of Entomology, and was of great service in diffusing exact knowledge of the use of sprays against this and other pests.

Control of plant diseases.-Very marked advance has been made in the control of many of the serious diseases which affect economic plants in this state. The following are a few of the most suggestive of these investigations:

1st. Black rot of grapes. Black rot is the most serious disease of grapes present in the State. The grape crop in the State is valued at $\$ 2,763,711$. It has been found that the key to the control of this disease is to spray before the rains and not after rains. The discovery and demonstration of this fact alone is worth many hundreds of thousands of dollars to grape-growers of the State.

2nd. Bean pod spot has been a very serious interruption to the bean industry, the annual crop of which in the State is valued at $\$ 2$,472,668 . It has been found that this disease can be practically controlled by the hand selection of pods free from the disease for seed the next year. This simple method will save the industry in this State.

3rd. Pear blight. This disease, which causes extensive damage to the fruit industries of the State, it has been found, can be practically controlled by systematic inspection, removal and disinfection of diseased parts. The demonstration of this method of control will save the pear-growing industry of the State much money.

4th. Apple scab. The control of this disease, which means so much to the successful prosecution of the apple industry, has heretofore been effected by the use of Bordeaux mixture, which frequently causes injury to the fruit. It has been demonstrated that lime-sulphur solution can be used as a substitute for Bordeaux, is just as effective in controlling the disease, and does not cause the fruit-injury produced by Bordeaux. It is believed that this discovery alone is worth more to the growers of the 
State than all the money which has been invested in the Plant Pathology investigations. The application of this practice will make possible a reduction of one-third the cost of spraying as given at present for this disease. It has been found, furthermore, that the lime-sulphur solution is a fairly effective treatment for peach leaf curl, which is also a serious disease in the State.

What is the value of agricultural surveys?-The Agricultural Surveys accomplish three important results :

1. They show in detail what are the agricultural resources of each township, and enable the College to supply local knowledge in such matters as soil adaptation, best rotations and most successful systems of management.

Frequently certain profitable practices that prevail in one section might be introduced to great advantage in another section which has the same natural conditions but where these practices have not been tried. The drainage of muck lands and the growing of truck crops on them is a very profitable system of farming. It is practiced in only a few isolated sections of the State. There are many other localities in which muck lands just as favorably situated may be found. A considerable area of the State, including some of what is known as the "abandoned farm" land in the southern part, is just as well adapted and located so far as soil, climate and railroads are concerned, for the production of apples as are Niagara, Orleans, Monroe or Wayne Counties. The fact that the soils of the cheap hill lands are well adapted to potatoes has been brought out by a survey. As a result of detailed knowledge of this sort gained in the surveys, the College is recommending and encouraging the adoption of these and other systems of farming wherever conditions are favorable and where they will pay better than the systems previously in vogue.

2. They supply material for studies of farm management. They enable the College to determine what are the factors conditioning success or failure.

The surveys have shown a striking relationship between the size of farms and profits. Contrary to the old impression that a "little farm well tilled" yielded the greatest profits, the surveys have proved conclusively that for general farming in the regions surveyed the largest farms are paying best. They have also shown that in spite of the high wages demanded for labor, the most successful farmers hire the most help. A study of the most successful farms upsets the old teaching that dairy farmers should raise their own grain and that they cannot afford 
to raise their own stock. These most successful farmers buy the most grain and raise their own stock. The amount of capital, machinery, and the number of horses, all have a direct relationship to profits. The surveys show why some farms are successful and why others are not.

3. They furnish the results of hundreds of experiments more cheaply than the College can conduct one. They show the relative productiveness of the various types of soils, the efficiency of different rotation systems, the comparative production of different breeds of dairy cattle, the effect of topography on crop production, and many other relationships, not in one instance under one set of conditions but on hundreds of farms and under a great variety of conditions.

Soil surveys.-The intelligent development of farm land must take into account the character of the soil and is determined by it. The soil survey, by determining the character of soils and their relation to crops and management on the one hand, outlines the problems confronting the farmer, and, on the other hand, presents them to the Experiment Stations for their solution in a manner which makes for most rapid progress. With the large number of farms which are offered for sale or exchange in New York State, the soil survey is the only reliable and thorough method by which the true values of such farms may be compared and studied. 


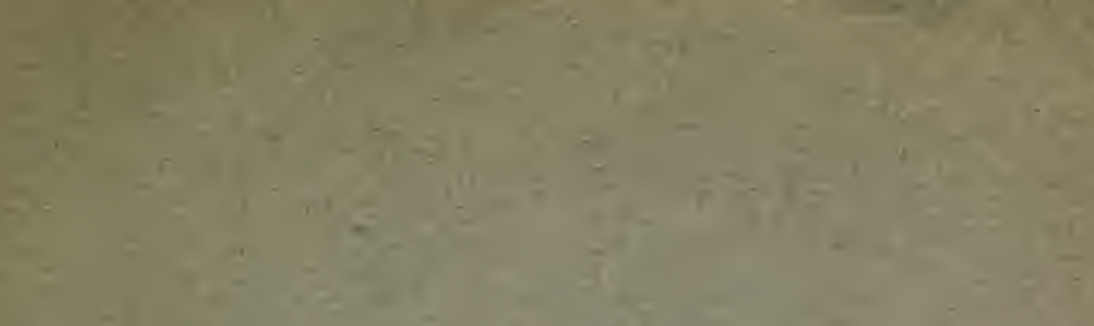

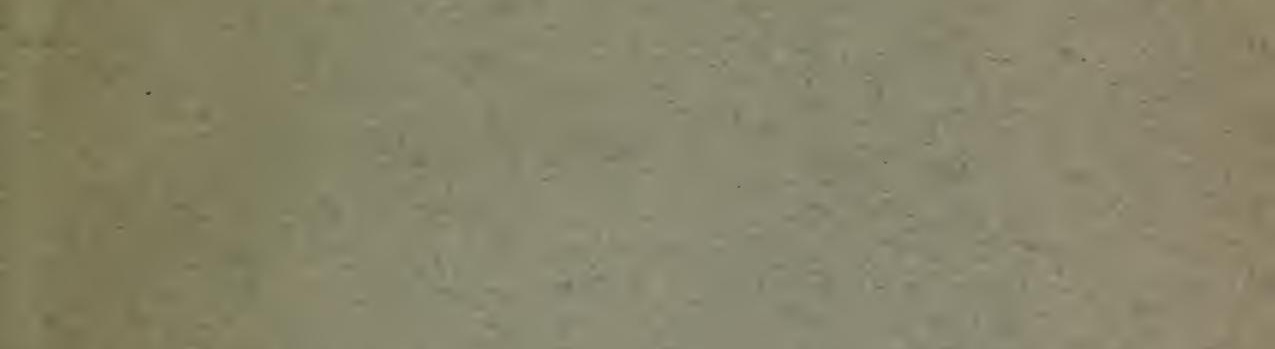
28,5

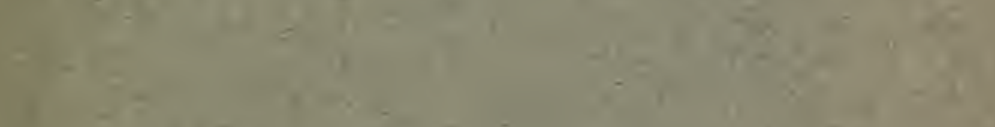

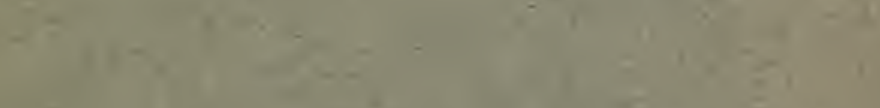

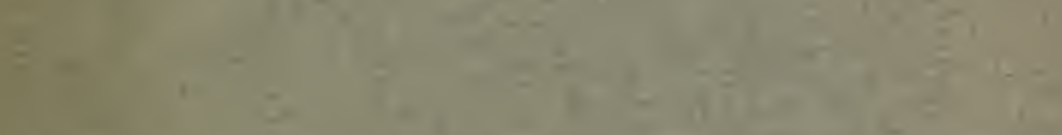

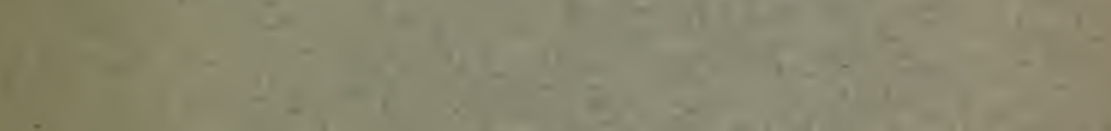
1.

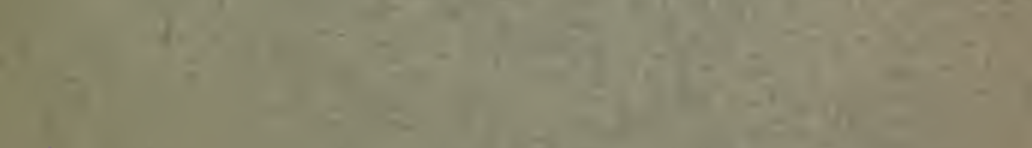

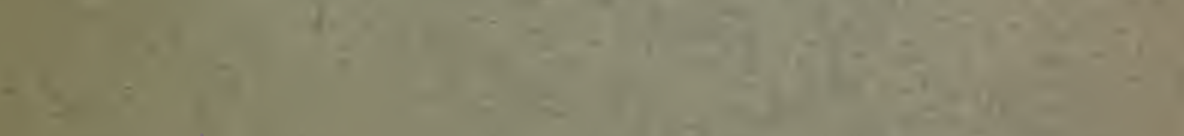

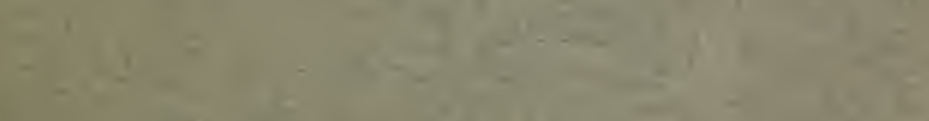




\section{UNIVERSITY OF CALIFORNIA LIBRARY}

\section{BERKELEY}

Return to desk from which borrowed.

This bolok is DUE on the last date stamped below.

NOY

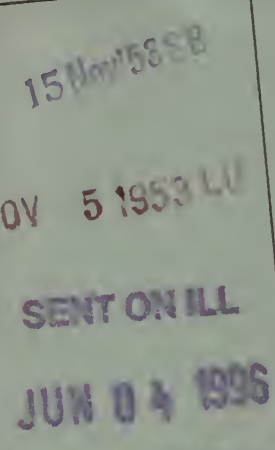

U. C. BEPKELEY 


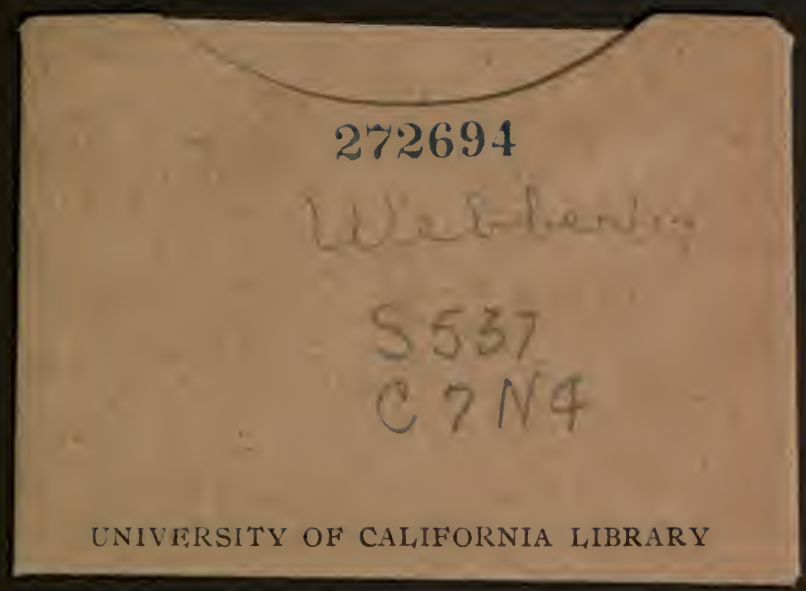

UNIVERSITY OF CALIFORNIA LIBRARY 
